\title{
Implementasi Kebijakan Rehabilitasi Pengguna Narkoba pada Badan Narkotika Nasional Provinsi Sumatera Barat
}

\author{
Silvia Fitri, Rahmadani Yusran \\ Jurusan Ilmu Administrasi Negara \\ FIS Universitas Negeri Padang \\ E-mail: Silviafitri31@gmail.com
}

\section{ABSTRAK}

Penelitian ini bertujuan menganalisis implementasi kebijakan rehabilitasi pengguna narkoba pada Badan Narkotika Nasional Provinsi Sumatera Barat. Sesuai dengan UU No 35 Tahun 2009 Tentang Narkotika, rehabilitasi dilakukan bertujuan melakukan pemulihan atau pengobatan, dan pengembalian kondisi bagi penyalahgunaan narkoba agar dapat kembali melaksanakan fungsi sosialnya yaitu melaksanakan kegiatan dalam masyarakat secara normal dan wajar. Penelitian ini merupakan penelitian kualitatif dengan menggunakan metode deskriptif. Informan penelitian ditentukan dengan cara purposive sampling. Teknik pengumpulan data dilakukan melalui wawancara, observasi, dan studi dokumentasi serta dilakukan reduksi data agar bisa ditarik kesimpulan yang akurat dari data yang telah didapat. Hasil penelitian menunjukkan bahwa implementasi kebijakan rehabilitasi pengguna narkoba pada Badan Narkotika Nasional Provinsi Sumatera Barat belum optimal dilaksanakan karena masih terkendala dalam beberapa indikator, seperti: proses komunikasi yang kurang serta sumber daya pendukung yang belum memadai baik dari sumber daya anggaran, sumber daya manusia, maupun sumber daya finansial, sehingga terjadinya kendala dalam implementasi.

Kata Kunci: implementasi kebijakan, rehabilitasi pengguna narkoba, BNN

\section{ABSTRACT}

This study aims to analyze the implementation of the policy of rehabilitation of drug users in the National Narcotics Agency of West Sumatra Province. Regulations regarding the policy of drug user rehabilitation are regulated in Law of the Republic of Indonesia Number 35 Year 2009 Regarding Narcotics. The purpose of rehabilitation is as a recovery or treatment, and the return of conditions for drug abuse in order to be able to return to carrying out its social functions, namely to be able to carry out activities in society normally and naturally. This research is a qualitative study using descriptive methods. Research informants were determined by purposive sampling. Data collection techniques are carried out by conducting interviews, observations, and documentation studies as well as data reduction so that accurate conclusions can be drawn from the data that has been obtained. The results showed that the implementation of the policy of rehabilitation of drug users in the National Narcotics Agency of West Sumatra Province was not optimally implemented because it was still constrained by several indicators, such as: inadequate communication processes and 
inadequate supporting resources both from budgetary resources, human resources, and financial resources, so that there are obstacles in implementation seen from the Policy Implementation Model according to George C. Edward III. Furthermore, the factors that influence the successful implementation of drug user rehabilitation policies at the National Narcotics Agency of West Sumatra Province, namely: socialization, low supporting resources, disposition, bureaucratic structure, and drug rehabilitation programs.

Keywords: policy implementation, drug user rehabilitation, BNN

(c) (7) (9) This work is licensed under the Creative Commons Attribution-ShareAlike 4.0 International License. BY SA C2020 by author.

Received: Jun $242020 \quad$ Revised: Agt $232020 \quad$ Accepted: Agt 242020

\section{PENDAHULUAN}

Narkoba telah menimbulkan akibat yang fatal terhadap masa depan bangsa. Peredaran narkoba dan banyaknya tertangkap bandar-bandar narkoba internasional akhir-akhir ini menjadi bukti bahwa Indonesia sedang dalam kondisi yang darurat. Peredaran narkoba ini sudah mencapai dan masuk keseluruh wilayah, tidak hanya di perkotaan saja, ke kampungkampung dan pelosok-pelosok juga sangat masif perkembangannya sekarang ini. Korbannya tidak hanya masyarakat biasa tetapi sudah masuk ke kalangan yang berpendidikan dan pejabat negara. Pengawasan negara juga lemah terhadap peredaran narkoba ini sehingga membuat para pengedarnya leluasa dalam menjalankan bisnisnya (Miswanto dan Tarya, 2017).

Merujuk Pasal 114 ayat (2) sub Pasal 112 ayat (2) UU No 35 Tahun 2009 tentang Narkotika yang menjelaskan bahwa narkotika di satu sisi merupakan obat atau bahan yang bermanfaat di bidang pengobatan atau pelayanan kesehatan dan pengembangan ilmu pengetahuan dan di sisi lain dapat pula menimbulkan ketergantungan yang sangat merugikan apabila disalahgunakan atau digunakan tanpa pengendalian dan pengawasan yang ketat dan seksama dengan ancaman minimal 5 tahun penjara dan maksimal hukuman mati. Pasal 54 UU No 35 Tahun 2009, menyatakan pecandu narkotika dan korban penyalahgunaan narkotika wajib menjalani rehabilitasi medis dan sosial. Rehabilitasi medis yakni terkait pengobatan dan pemulihan kesehatan. Sedangkan rehabilitasi sosial terkait pemulihan sosial dan mental pecandu narkoba. PP Nomor 25 Tahun 2011 tentang Pelaksanaan Wajib Lapor Pecandu Narkotika. Wajib lapor adalah kegiatan melaporkan diri yang dilakukan oleh pecandu Narkotika yang sudah cukup umur atau keluarganya, dan orang tua atau wali dari pecandu Narkotika yang belum cukup umur kepada institusi penerima wajib lapor untuk mendapatkan pengobatan dan atau perawatan melalui rehabilitasi medis dan rehabilitasi sosial (Haerana, 2016).

Berdasarkan peraturan tersebut di atas, pecandu narkotika dan korban penyalahgunaan narkotika yang tanpa hak dan melawan hukum sebagai tersangka dan atau terdakwa dalam 
penyalahgunaan narkotika yang sedang menjalani proses penyidikan, penuntutan, dan persidangan di pengadilan diberikan pengobatan, perawatan dan pemulihan dalam lembaga rehabilitasi. Penentuan apakah layak direhabilitasi atau tidak, tetap melalui putusan pengadilan. Hal ini diperjelas dalam Peraturan Kepala Badan Narkotika Nasional Pasal 3 ayat (1) no. 11 Tahun 2014 tentang Tata Cara Penanganan Tersangka dan/atau Terdakwa Pecandu Narkotika dan Korban Penyalahgunaan Narkotika ke Dalam Lembaga Rehabilitasi (Peraturan BNN 11/2014). Dalam hal ini berdasarkan UU maka negara bertanggung jawab untuk memulihkan para pengguna narkoba melalui rehabilitasi.

Oleh karena itu sudah sepatutnya tak boleh ada kendala untuk program rehabilitasi, termasuk mengenai infrastruktur atau fasilitas pemulihan para pecandu narkoba. Dengan demikian seharusnya penerapan rehabilitasi pengguna narkoba adalah suatu keharusan kepada setiap pengguna, sehingga rehabilitasi tidak boleh digantungkan kepada kemampuan bayar dari masing-masing pengguna narkoba. Masyarakat juga harus berani untuk bersikap tegas apabila mendapati ada oknum aparat yang meminta uang jutaan rupiah agar pengguna dapat direhabilitasi. Masyarakat dapat melaporkan oknum tersebut ke lembaga pengawas kepolisian seperti Divisi Propam atau Komisi Kepolisian Nasional (Kompolnas). Apabila yang meminta adalah hakim, maka dilaporkan ke Komisi Yudisial (Rasdianah dan Nur, 2018).
Dalam PerMenKes RI Pasal 1 ayat (8) No 252011 tentang rehabilitasi medis pecandu, penyalahguna dan korban penyalahgunaan narkoba menjelaskan bahwa fasilitas rehabilitasi medis adalah tempat yang digunakan untuk menyelenggarakan pelayanan rehabilitasi penyalahgunaan dan ketergantungan Narkotika, melalui kegiatan pengobatan secara terpadu baik fisik, psikis, spiritual dan sosial. Pasal 9 ayat (1) Proses rehabilitasi medis meliputi asesmen, penyusunan rencana rehabilitasi, program rehabilitasi rawat jalan atau rawat inap, dan program pasca rehabilitasi. Menurut Miswanto dan Tarya (2017), Faktor yang mempengaruhi keberhasilan rehabilitasi adalah: (1) Sarana dan prasarana. Faktor sarana dan prasarana yang mendukung mencakup tenaga manusia yang berpendidikan dan terampil, organisasi yang baik, peralatan yang memadai, keuangan yang cukup. Tanpa sarana dan prasana yang memadai, rehabilitasi tidak dapat berjalan dengan lancar. (2) Sumber Daya Manusia. Meningkatkan konselor adiksi sebagai salah satu SDM yang dibutuhkan dalam program rehabilitasi narkoba. (3) Program. Menjalankan dengan baik program rehabilitasi narkoba, program tersebut adalah: program rawat inap awal, program lanjutan, program pasca rawat.

Di Sumatera Barat, kasus narkoba merupakan kasus yang tertinggi jumlahnya di Indonesia. Dimana angka kasus narkoba sudah mencapai 37,73 persen. Hal ini dilihat dari meningkatnya jumlah kasus narkoba dari tahun ke tahun. Pada tahun 2015 terdapat 635 kasus 
narkoba, tahun 2016 sebanyak 824 kasus (Padangkita, 2017). Pada tahun 2017 sebanyak 819 kasus, dan tahun 2018 kasus tertinggi yaitu sebanyak 926 kasus (Padek, 2019). Pada tahun 2018 para pengguna narkoba yang mayoritasnya adalah generasi muda atau para pelajar. Kondisi ini membuat provinsi Sumatera Barat menduduki posisi ke-13 dari seluruh provinsi di Indonesia (Merdeka, 2018). Tujuan rehabilitasi menurut UU No 35 Tahun 2009 tentang Narkotika adalah sebagai pemulihan atau pengobatan dan pengembalian kondisi bagi penyalahgunaan narkoba agar dapat kembali melaksanakan fungsi sosialnya yaitu dapat melaksanakan kegiatan dalam masyarakat secara normal dan wajar. Pada BNN Provinsi Sumatera Barat dalam hal pemulihan belum dilaksanakan secara optimal.

Pertama, masih kurangnya kesadaran baik dari pihak keluarga maupun dari pihak pengguna narkoba itu sendiri. Ini dikarenakan tidak adanya dukungan dari keluarga. Kurang adanya perhatian keluarga merupakan salah satu hambatan pengasuh dalam upaya penyadaran. Kurangnya dukungan tersebut dapat dilihat dari sedikitnya orang tua atau keluarga yang mengunjungi anaknya di tempat rehabilitasi narkoba. Kedua, sarana dan prasarana rehabilitasi masih terbatas yang mana terlihat dari BNN Sumbar hanya memiliki sarana dan prasarana rawat jalan seperti klinik, sedangkan untuk sarana dan prasarana rawat inap belum dimiliki. Padahal sarana dan prasarana rehabilitasi ini sangat diperlukan untuk kelancaran pengobatan maupun pemulihan bagi pengguna narkoba.

Ketiga, belum optimalnya akses dan kualitas layanan rehabilitasi dalam upaya memulihkan penyalahgunaan dan pecandu dari ketergantungan narkoba. Hal ini dapat dilihat dari program rehabilitasi terhadap penyalah guna narkoba tidak hanya fokus pada layanan berbasis panti, namun harus menyentuh atau mengintervensi langsung pada masyarakat. Saat ini, banyak penyalahgunaan narkoba telah merambah hingga ke daerah terpencil. Jika mereka harus mengakses pusat rehabilitasi di kota-kota besar, maka hal itu akan sulit dan pasti memerlukan biaya untuk ke kota.

Selain itu, program layanan, kompetensi petugas dan kelengkapan sarana serta prasarana pendukungnya, dengan menggunakan instrumen atau alat ukur yang memadai serta dilakukan secara periodik belum optimal dilaksanakan. Keempat, masih kurangnya kesadaran masyarakat terhadap akibat yang ditimbulkan oleh ketergantungan narkoba. Hal ini disebabkan karena kurangnya pemahaman masyarakat tentang efek yang ditimbulkan oleh narkoba. Masyarakat dituntut untuk memahami efek yang ditimbulkan oleh narkoba agar tidak terjerumus dalam narkoba.

\section{METODE PENELITIAN}

Penelitian ini menggunakan pendekatanan kualitatif dengan metode deskriptif. Lokasi penelitian adalah pada Badan Narkotika Nasional Provinsi Sumatera Barat. Secara umum metode penelitian kualitatif adalah sebuah metode riset yang sifatnya deskriptif, menggunakan analisis, mengacu pada data, dan memanfaatkan teori yang ada sebagai bahan pendukung, serta menghasilkan suatu teori. Menurut Creswell (2010:4). 
Informan

menggunakan teknik purposive sampling. Informan dipilih berdasarkan karakteristik orang-orang yang benar-benar memahami permasalahan yang diteliti. Adapun informan penelitian ini adalah Kepala Bidang Rehabilitasi Badan Narkotika Nasional Provinsi Sumatera Barat, Kasi Pascarehabilitasi, Pelaksana Program Rehabilitasi, Staff dan Pegawai Bidang Rehabilitasi, dan Beberapa Pasien Rehabilitasi Pengguna Narkoba. Teknik pengumpulan data dilakukan melalui wawancara, observasi, dan studi dokumentasi. Uji keabsahan data penulis menggunakan teknik triangulasi dan menggunakan bahan referensi. Selanjutnya, data yang diperoleh akan dianalisis melalui tahap reduksi data, penyajian data dan penarikan kesimpulan.

\section{HASIL DAN PEMBAHASAN}

Implementasi Kebijakan Rehabilitasi Pengguna Narkoba

$$
\text { Implementasi kebijakan }
$$

berkaitan erat dengan upaya untuk mewujudkan capaian tujuan kebijakan. Melalui berbagai aktivitas implementasi, tujuan kebijakan dilaksanakan dalam bentuk aktivitas secara sistematis (Aprina, Y \& Yusran, R., 2020). Dengan demikian, dalam konteks kebijakan rehabilitasi pengguna narkoba di BNNP Sumbar adalah merupakan rangakaian aktivitas yang dilakukan untuk mewujudkan capaian dari tujuan kebijakan rehabiliatasi pengguna narkoba.

Berdasarkan temuan penelitian, program rehabilitasi narkoba di BNNP dilaksanakan dalam tiga bentuk.
Pertama, rehabilitasi rawat jalan. Rehabilitasi rawat jalan adalah pemeriksaan konseling secara berkala dalam waktu kurang lebih selama tiga bulan. Pada rehabilitasi rawat jalan klien hanya dilakukan pemeriksaan dan konseling secara berkala. Program rehabilitasi rawat jalan relatif mampu memperbaiki derajat keparahan zat, keterlibatan pada tindak kriminal, dan permasalahan gangguan psikiatri pada klien. Pada saat pemeriksaan medis, klien diberikan terapi obat seperti: methadone dan naltrexone. Namun, obat ini memiliki beberapa efek samping dan hanya diberikan pada pasien rawat jalan, setelah klien menerima pengobatan detoksifikasi.

Naltrexone berguna untuk menghalangi efek narkoba berupa perasaan senang, bahagia, sehat, dan meredanya rasa sakit, serta mengurangi keinginan untuk mengonsumsi narkoba. Sedangkan untuk konseling yang dilakukan oleh konselor terhadap pengguna narkoba dalam rehabilitasi akan membantu klien mengenali masalah atau perilaku yang memicu ketergantungan tersebut. Konseling merupakan bagian penting dalam mengobati penyalahgunaan narkoba. Konseling biasanya dilakukan secara individu. Meski demikian, tak tertutup kemungkinan untuk melakukan konseling secara berkelompok. Konseling bertujuan untuk membantu program pemulihan, seperti memulai kembali perilaku hidup sehat ataupun strategi menghadapi situasi yang berisiko penggunaan narkoba kembali terulang.

Konselor bertanggung jawab untuk memahami bagaimana kecanduan narkoba pada seseorang 
secara keseluruhan, sekaligus memahami lingkungan sosial yang ada di sekitarnya untuk mencegah terulangnya penyalahgunaan narkoba. Penanganan untuk mengatasi dampak ketergantungan narkoba perlu melibatkan berbagai aspek lainnya, seperti aspek sosial dan dukungan moral dari orang terdekat dan lingkungan sekitar. Tak jarang pecandu narkoba dapat kembali beraktivitas normal dan menjalani hidup dengan lebih baik setelah menjalani penanganan medis, ditambah dukungan moral dan sosial yang baik.

Selama, mengikuti konseling ini klien mendatangi klinik pratama BNNP sebanyak 8-12 kali pertemuan. Apabila, klien dinyatakan belum pulih, maka BNNP merekomendasikan untuk rawat inap ke rumah sakit yang sudah bekerjasama. Pelaksanaan rehabilitasi rawat jalan ini, sudah dilaksanakan sesuai dengan peraturan yang ada. Artinya, klien pengguna narkoba yang melakukan rawat jalan sudah mengkuti program rehabilitasi sebagaimana mestinya.

Kedua, rehabilitasi rawat inap. dilaksanakan untuk pecandu dan korban penyalahgunaan narkotika dengan tingkat penggunaan sedang sampai berat berdasarkan rencana terapi dan sesuai dengan diagnosis yang telah di tegakkan. Untuk rawat inap berupa intervensi medis antara lain melalui program detoksifikasi, terapi simtomatik, dan terapi penyakit komplikasi sesuai indikasi yang kemudian masuk ke intervensi psikososial antara lain melalui konseling individual, kelompok, keluarga, dan vokasional. Di BNNP
Sumatera Barat, rawat inap ini tidak dilaksanakan. Hal ini, disebabkan karena BNNP tidak memiliki fasilitas rawat inap. Akan tetapi, untuk rawat inap dilaksanakan bekerjasama dengan beberapa rumah sakit di bawah Kementerian Kesehatan. Misalnya, RSJ HB Saanin Kota Padang dan Lido Loka Rehabilitasi BNN di Batam.

Ketiga, pasca rehabilitasi merupakan tahapan pembinaan lanjut yang diberikan kepada mantan pecandu narkoba yang telah menjalani rehabilitasi medis dan rehabilitasi sosial, guna mempertahankan kepulihannya. Rehabilitasi Medis adalah suatu proses kegiatan pengobatan secara terpadu untuk membebaskan pecandu dari ketergantungan narkotika. Penelitian ini menemukan pasca rehabilitasi dilaksanakan di dua tempat. Pertama, pasca rehabilitasi yang dilakukan di rumah damping yang telah disediakan BNNP Sumatera Barat. Selama di rumah damping klien pengguna narkoba difasilitasi kegiatan berupa pengembangan bakat dalam membentuk keterampilan kreativitas, menjahit, seni lukis dan melaksanakan kegiatan group terapi layanan pasca rehabilitasi berkaitan dengan sugesti atau craving.

Pada kegiatan group therapy ini dilakukan sebanyak empat kali, sedangkan untuk family therapy satu kali. Selanjutnya ada kegiatan seminar pengembangan yang dilakukan oleh klien sebanyak dua kali. Pada seminar pengembangan ini nanti pelaksana mengundang fasilisator dari luar sesuai kebutuhan, seperti: psikologi, narasumber balai kerja latihan, keagamaan seperti ustad. Ini tergantung kebutuhan klien. Selama 
Journal of Civic Education (ISSN: 2622-237X)

Volume 3 No. 32020

pelaksanaan program ini nanti ada pemeriksaan urine sebanyak 2x. Pada pascarehab intensif, klien dimasukkan kerumah damping yang sifatnya rawat inap selama 50 hari yang di prioritaskan itu klien yang usia produktif, yang tidak bekerja, dan belum berkeluarga. Rumah damping ini diutamakan kepada klien yang rehab inap. Selama pelaksanaan program ini nanti ada pemeriksaan urine sebanyak 3x. Selanjutnya yaitu dilakukan pascarehab lanjut.

Tabel 1 Target Program Pasca Rehab

\begin{tabular}{|c|c|c|c|c|}
\hline $\begin{array}{l}\text { Tahun } \\
\text { (Taerget) }\end{array}$ & $\begin{array}{c}\text { Pulih } \\
\text { Produktif }\end{array}$ & $\begin{array}{c}\text { Pulih } \\
\text { Tidak } \\
\text { Produktif }\end{array}$ & $\begin{array}{c}\text { Tidak } \\
\text { pulih } \\
\text { Produktif }\end{array}$ & $\begin{array}{c}\text { Tidak } \\
\text { Pulih } \\
\text { dan } \\
\text { Tidak } \\
\text { Produktif }\end{array}$ \\
\hline 2018 & & & & \\
\hline $\begin{array}{c}(100 \\
\text { orang) }\end{array}$ & 79 orang & 8 orang & 7 orang & 6 orang \\
\hline 2019 & & & & \\
\hline $\begin{array}{c}(83 \\
\text { orang) }\end{array}$ & 49 orang & 19 orang & 6 orang & 9 orang \\
\hline
\end{tabular}

*Sumber tabel: Data olahan dari BNNP Sumatera Barat

Namun demikian, capaian dari tujuan kebijakan rehabilitasi pengguna narkoba pada BNNP Sumatera Barat belum optimal dilakukan. Secara makro program rehabilitasi terbatas pelaksanaannya. Hal ini, karena jumlah angka kunjungan klien yang rendah melakukan rehabilitasi. Fenomena ini, juga dipengaruhi oleh rendahnya kesadaran klien melakukan rehabilitasi narkoba. Berdasarkan temuan penelitian, rendahya kesadaran klien mengkuti rehabilitasi narkoba disebabkan karena tidak adanya motivasi dan dukungan dari keluarga. Sehingga berdampak kepada proses rehabilitasi yang dilakukan oleh pihak BNNP Sumatera Barat.
Faktor yang Mempengaruhi Implementasi Kebijakan Rehabilitasi Pengguna Narkoba

Berdasarkan Undang-Undang No 35 Tahun 2009, Rehabilitasi pengguna narkoba bertujuan sebagai pemulihan dan pengembalian kondisi bagi penyalahgunaan narkoba agar dapat kembali melaksanakan fungsi sosialnya yaitu dapat melaksanakan kegiatan dalam masyarakat secara normal dan wajar. Dalam penerapan kebijakan rehabilitasi pengguna narkoba terdapat faktor-faktor yang mempengaruhi implementasi keberhasilan rehabilitasi, yaitu: sosialisasi, rendahnya sumber daya pendukung, disposisi, struktur birokrasi dan program rehabilitasi narkoba.

a) Sosialiasi

Implementasi kebijakan publik agar dapat mencapai keberhasilan, mensyaratkan agar implementor mengetahui apa yang harus dilakukan secara jelas. Apa yang menjadi tujuan dan sasaran kebijakan harus diinformasikan kepada kelompok sasaran, sehingga dapat mengurangi distorsi implementasi. Hal ini, menjadi penting mengurangi tingkat penolakan dan kekeliruan mengaplikasikan program atau kebijakan. Selain itu untuk mencapai keberhasilan bisa dilakukan juga dengan adanya komunikasi antar organisasi. Komunikasi dalam melaksanakan kebijakan diperlukan mendukung keberhasilan kebijakan. Ketika komunikasi dilakukan dengan baik, maka tugas dan kewajiban mereka dapat berjalan dengan baik dan para implementor akan lebih konsisten dalam melaksanakan kebijakan. 
Berdasarkan temuan di lapangan, pelaksanaan sosialisasi yang dilakukan oleh BNNP Sumatera Barat terkait dengan kebijakan rehabilitasi pengguna narkoba proses komunikasi yang disampaikan dalam tahap tertentu sudah terlaksana. Namun demikian, ada kalanya faktor sosialisasi mengalami kendala.

Kendalanya adalah saat sosialisasi sedang berlangsung banyak masyarakat yang kurang paham dengan maksud dan tujuan dilakukannya rehabilitasi pengguna narkoba, akibatnya dukungan masyarakat terhadap pelaksaan kebijakan rehabilitasi pengguna narkoba pada BNNP Sumatera Barat berkurang.

Kendala lainnya adalah kurangnya kesadaran klien yang mengakibatkan angka kunjungan pengguna narkoba di BNNP rendah sehingga staff BNNP turun langsung kelapangan untuk mencari data klien yang menggunakan narkoba ke kelurahan. Nanti setelah mendapatkan data dari kelurahan, BNNP akan mengunjungi rumah klien untuk dimintak agar klien mau direhabilitasi. Mestinya sebagaimana yang diungkapkan oleh George C. Edward III, komunikasi itu harus dilaksanakan secara komprehensif terhadap kelompok-kelompok masyarakat yang menjadi sasaran dari kebijakan rehabilitasi pengguna narkoba dan tidak hanya terbatas dilakukan pada kelompok masyarakat tertentu saja. Inilah faktor yang mempengaruhi keberhasilan komunikasi implementasi kebijakan rehabilitasi pengguna narkoba pada BNNP.

b) Rendahnya Sumberdaya Pendukung Implementasi Kebijakan
Menurut George C. Edward III, Sumber daya merupakan salah satu variabel yang mempengaruhi keberhasilan implementasi suatu kebijakan. Setiap kebijakan harus didukung oleh sumber daya yang memadai, baik sumber daya anggaran, sumber daya manusia maupun sumber daya finansial. Menurut George C. Edward III, Sumberdaya anggaran berkaitan dengan kecukupan modal atas suatu program atau kebijakan untuk menjamin terlaksananya kebijakan. Sebab tanpa dukungan anggaran yang memadai, kebijakan tidak akan berjalan dengan efektif dalam mencapai tujuan dan sasaran. Sumber daya manusia meliputi kecukupan baik kualitas maupun kuantitas implementor yang dapat melingkupi seluruh kelompok sasaran. Sedangkan sumber daya finansial meliputi fasilitas atau sarana dan prasarana yang mana merupakan salah satu faktor yang berpengaruh dalam implementasi kebijakan.

Rendahnya sumber daya pendukung implementasi kebijakan rehabilitasi pengguna narkoba pada BNNP Sumatera Barat dipengaruhi oleh keterbatasan anggaran. Berdasarkan temuan di lapangan, selama ini anggaran rehabilitasi pengguna narkoba berasal dari APBN. Dana yang digunakan masuk dalam Daftar Isian Pelaksanaan Anggaran (DIPA) APBN. Anggaran ini terbatas, sehingga tidak memadai dalam hal obat-obatan dan fasilitas. Untuk memenuhi keterbatasan anggaran ini maka penanggung jawab dalam implementasi kebijakan rehabilitasi pengguna narkoba pada BNNP berusaha untuk mensubsidikan anggaran lain yang tersedia, agar dalam melaksanakan kebijakan 
rehabilitasi pengguna narkoba dapat terkendalikan.

Kemudian, rendahnya sumberdaya pendukung implementasi kebijakan rehabilitasi pengguna narkoba pada BNNP Sumatera Barat lainnya adalah sumber daya manusia. Mengacu kepada George C. Edward III sumber daya manusia dalam implementasi kebijakan berkaitan dengan ketersediaan staff/pegawai yang berkompeten dibidangnya. Berdasarkan temuan di lapangan, jumlah staff pelaksana kebijakan rehabilitasi pengguna narkoba pada BNNP belum memadai karena terbatasnya pelaksana tugas. Keterbatasan ini mempengaruhi keberhasilan kebijakan rehabilitasi pengguna narkoba sehingga kesulitan dalam melakukan sosialisasi atau kegiatan lainnya. Untuk mengatasi keterbatasan sumber daya manusia BNNP merolling staff dan pegawai dari bidang satu ke bidang yang lainnya. Keterbatasan sumber daya manusia ini berdampak pada tingkat pemahaman masyarakat terhadap pentingnya pelaksanaan kebijakan rehabilitasi. Selain itu, keberhasilan implementasi kebijakan rehabilitasi pengguna narkoba ini sangat butuh dukungan keluarga dan lingkungan.

Selanjutnya, rendahnya sumber daya pendukung implementasi kebijakan pengguna rehabilitasi pada BNNP Sumatera Barat adalah sumber daya finansial. Sumber daya finansial meliputi fasilitas atau sarana dan prasarana. Pengadaan fasilitas yang layak, seperti gedung, tanah dan peralatan perkantoran akan menunjang dalam keberhasilan implementasi suatu program atau kebijakan. Berdasarkan temuan di lapangan, sarana dan prasarana belum memadai. Misalnya keterbatasan dari ruangan rawat jalan yang belum memadai untuk sebuah klinik pratama yang ada di BNNP Sumatera Barat. Selain itu, untuk rawat inap BNNP tidak memiliki, tetapi bekerja sama dengan Rumah sakit dan Kementerian Kesehatan, sehingga untuk klien yang rawat inap diinapkan di rumah sakit dan di Kementerian Kesehatan yang bekerjasama dengan BNNP Sumatera Barat. Faktor ini menyulitkan pihak BNNP dalam melaksanakan kebijakan rehabilitasi pengguna narkoba. Akibatnya implementasi kebijakan rehabilitasi pengguna narkoba pada BNNP belum optimal dilaksanakan. Inilah faktor yang mempengaruhi keberhasilan sumber daya pendukung implementasi kebijakan rehabilitasi pengguna narkoba pada BNNP Sumatera Barat.

c) Disposisi

Disposisi atau sikap dari pelaksana kebijakan adalah faktor penting ketiga dalam pendekatan mengenai pelaksanaan suatu kebijakan publik. Sikap dari pelaksana akan mempengaruhi keberhasilan atau tidaknya suatu kebijakan. Pelaksanaan kebijakan rehabilitasi pada BNNP Sumatera Barat mendapat dukungan dan respon positif dari para pelaksana dalam bentuk komitmen mereka dalam menjalankan kebijakan rehabilitasi. Bentuk komitmen tersebut ditujukkan dengan sikap melayani masyarakat tanpa pamrih serta memehami tugas dan fungsinya masing-masing pada saat pelaksanaan kebijakan. Selain itu pelaksana juga melaksanakan pelatihan yang diberikan oleh BNNP. Dengan adanya pemahaman tentang kebijakan 
rehabilitasi ini akan memudahkan pelaksana untuk melaksanakan kebijakan rehabilitasi.

Peneliti mewawancarai pengguna narkoba (klien) rawat jalan, yang mana sikap dari pelaksana juga mendapat dukungan dan respon positif dari para klien. Pelaksana memberi dukungan atau motivasi, memberi tahu efek pemakai narkoba sehingga para klien semangat untuk menjalani proses rehabilitasi. Para klien mengaku bahwa pelaksana ini perannya bagus sehingga bisa dikatakan sikap dari pelaksana kebijakan sudah efektif. BNNP Sumatera Barat sebagai pelaksana kebijakan rehabilitasi sudah menjalankan kebijakan dan berkomitmen mendukung kebijakan rehabilitasi sehingga kebijakan berjalan dengan baik.

Sikap pelaksana sudah bagus yang terlihat dalam komitmen serta kejujuran pihak penyelenggara dalam melaksanakan tugasnya yang selalu berpedoman pada peraturan yang sudah ditetapkan oleh BNN Pusat (Tingat Eselon I), seperti: UU No.35 Tahun 2009, Peraturan Kepala BNN No. 11 Tahun 2014. Berdasarkan uraian diatas dapat dikatakan implementasi kebijakan rehabilitasi pengguna narkoba BNNP Sumatera Barat dalam aspek disposisi sudah sesuai dengan pendapat George C. Edward III.

d) Struktur Birokrasi

Dalam pengimplementasian kebijakan struktur birokrasi menjadi aspek yang sangat penting. Aspek struktur birokrasi ini mencakup dua hal penting, yaitu: mekanisme dan struktur. Mekanisme implementasi kebijakan biasanya sudah ditetapkan melalui Standar Operating Procedur
(SOP) yang dicantumkan dalam pedoman kebijakan/program. SOP yang baik mencamtukan kerangka kerja yang jelas, sistematis, tidak berbelit dan mudah dipahami oleh siapapun karena akan menjadi acuan dalam bekerjanya implementor. Sedangkan untuk struktur organisasi pelaksana pun sejauh mungkin menghindari hal yang berbelit, panjang dan kompleks. Struktur organisasi pelaksana harus dapat menjamin adanya pengambilan keputusan atas kejadian luar biasa dalam program secara cepat.

Berdasarkan temuan di lapangan, dalam pengimplementasian kebijakan pengguna narkoba pada BNNP Sumatera Barat disposisinya lancar, struktur birokrasi yang ada baik, dan tidak terlalu berbelit-belit dalam kepengurusan kebijakan rehabilitasi pengguna narkoba. Hal ini terlihat dari prosedur kerja implementor dalam menangani klien yang sesuai dengan Pasal 8 sampai dengan pasal 18 Peraturan Kepala BNN No. 11 Tahun 2014 tentang tata cara penanganan tersangka dan/atau terdakwa pecandu narkotika dan korban penyalahgunaan narkotika ke dalam lembaga rehabilitasi.

Berdasarkan uraian diatas
dapat dikatakan implementasi
kebijakan rehabilitasi pengguna
narkoba BNNP Sumatera Barat dalam
aspek struktur birokrasi sudah sesuai
dengan pendapat George C. Edward
III.

\section{KESIMPULAN}

Capaian dari tujuan kebijakan rehabilitasi pengguna narkoba pada BNNP Sumatera Barat belum optimal dilakukan. Misalnya dari aspek pelaksanaan. Untuk rawat jalan dan 
pasca rehabilitasi sudah dijalankan, tetapi ada kendalanya yaitu keterbatasan dana. Kedua aspek sarana dan prasarana yang belum memadai dikarenakan ruangan di BNNP Sumatera Barat masih kurang. Ketiga aspek sumber daya manusia terbatas tetapi masih bisa dimaksimalkan. Karena SDM terbatas sehingga tenaga kerja yang lain harus mengambil pekerjaan yang sebenarnya belum tentu bidang dia sehingga SDM dikatakan belum optimal.

$\begin{array}{lcr}\quad \text { Dalam } & \text { penerapan } & \text { kebijakan } \\ \text { rehabilitasi } & \text { pengguna } & \text { narkoba } \\ \text { terdapat } & \text { faktor-faktor } & \text { yang }\end{array}$
mempengaruhi implementasi keberhasilan rehabilitasi, dalam aspek lainnya seperti sosialisasi sudah terlaksana, namun belum mampu meningkatkan pemahaman masyarakat tentang maksud dan tujuan dari kebijakan rehabilitasi pengguna narkoba. Dari segi sumber daya pendukung selama ini BNNP Sumatera Barat anggarannya berasal dari APBN. Anggaran ini terbatas sehingga harus mensubsidikan anggaran lain yang tersedia untuk memenuhi keterbatasan anggaran terutama dalam hal obat-obatan dan fasilitas. Kemudian, dalam aspek sumber daya manusia juga mengalami keterbatasan staff dalam melaksanakan kebijakan rehabilitasi pengguna narkoba, sehingga mengakibatkan rendahnya capaian dari tujuan rehabilitasi. Selanjutnya, dalam aspek sumber daya finansial terutama sarana dan prasarana di BNNP Sumatera Barat belum memadai, seperti ruangan yang tidak memadai untuk pasien rawat jalan, dan untuk rawat inap BNNP Sumatera Barat tidak memiliki. Faktor ini menyulitkan pihak BNNP Sumatera Barat melaksanakan kebijakan rehabilitasi pengguna narkoba.

\section{DAFTAR PUSTAKA}

Aprina, Y., \& Yusran, R. (2020). Implementasi Peraturan Daerah Kota Bukittinggi Nomor 2 Tahun $2015 \quad$ Tentang Pencegahan Dan Penanggulangan Bahaya Kebakaran. Jurnal Mahasiswa Ilmu Administrasi Publik, 1(4), 87-97. Retrieved from http://jmiap.ppj.unp.ac.id/ind ex.php/jmiap/article/view/49

Craswell, John W. 2010. Research Design: Pendekatan Kualitatif, Kuantitatif, dan Mixed. Yogyakarta: PT Pustaka Pelajar.

Dr. H. Rusdin Nawi. 2017. Perilaku Kebijakan Organisasi. Makassar: CV Sah Media.

Dr. H. Tachjan. 2006. Implementasi Kebijakan Publik. Bandung: AIPI Bandung.

Haerana. 2016. Implementasi Kebijakan Rehabilitasi Pengguna Narkoba Di Kota Makassar. Jurnal Administrasi Publik. Vol. 06, No. 02. Universitas Muhammadiyah Makassar.

Moleong, Lexy. J. 2011. Metodologi Penelitian Kualitatif. Bandung: PT Remaja Rosdakarya.

Miswanto, Tarya. 2017. Implementasi Program Rehabilitasi Narkoba Berbasis Masyarakat di Pusat Rehabilitasi Narkoba arRahman Tegal Binangun Palembang. Jurnal Intizar. Vol. 23, No. 01. UIN Raden Fatah Palembang.

Peraturan Daerah Provinsi Sumatera Barat Nomor 9 Tahun 2018 
242 | implementasi kebijakan..

Tentang Fasilitasi Pencegahan Penyalahgunaan Narkotika, Psikotropika Dan Zat Adiktif Lainnya

Peraturan Kepala Badan Narkotika Nasional Nomor 11 Tahun 2014 Tentang Tata Cara Penanganan Tersangka Dan/Atau Terdakwa Pecandu Narkotika Dan Korban Penyalahgunaan Narkotika Ke Dalam Lembaga Rehabilitasi

Peraturan Menteri Kesehatan Republik Indonesia Nomor 2415/Menkes/ Per/Xii/2011 Tentang Rehabilitasi Medis Pecandu, Penyalahguna Dan Korban Penyalahgunaan Narkotika.

Peraturan Menteri Kesehatan Republik Indonesia Nomor 50 Tahun 2015 Tentang Petunjuk

Teknis Pelaksanaan Wajib Lapor Dan Rehabilitasi Medis Bagi Pecandu, Penyalahguna, Dan Korban Penyalahgunaan Narkotika.

Peraturan Menteri Sosial Republik Indonesia Nomor 26 Tahun 2012 Tentang Standar Rehabilitasi Sosial Korban Penyalahgunaan Narkotika, Psikotropika, dan Zat Adiktif Lainnya.

Peraturan Pemerintah Republik Indonesia Nomor 25 Tahun 2011 Tentang Pelaksanaan Wajib Lapor Pecandu Narkotika.

Prof. Dr. H. Solichin Abdul Wahab. 2014. Analisis Kebijakan: Dari Formulasi ke Penyusunan Model-Model Implementasi Kebijakan Publik. Jakarta : PT Bumi Aksara.
Rasdianah, Fuad Nur. 2018. Efektivitas Pelaksanaan Rehabilitasi Medis Terhadap Pecandu Dan Korban Penyalahgunaan Narkotika. Jurnal Jurisprudentie. Vol. 05, No. 02. Universitas Ichsan Gorontalo.

Sagung Putri, dkk. 2016. Program Rehabilitasi Bagi Penyalahgunaan Narkotika Dalam Persfekti UndangUndang No 35 Tahun 2009 Tentang Narkotika. Jurnal Ilmiah. Vol. 38, No. 01. Universitas Udayana.

Seto Michiko. 2016. Pelayanan Rehabiltasi Badan Narkotika Nasional Provinsi Jawa Timur Terhadap Penyalahguna Narkoba. Jurnal Administrasi Publik. Vol. 14, No. 1. Universitas 17 Agustus 1945 Surabaya.

Undang-Undang No. 35 Tahun 2009 Tentang Narkotika. 